\title{
HUMAN AGENCY, ENVIRONMENTAL DRIVERS, AND WESTERN JUNIPER ESTABLISHMENT DURING THE LATE HOLOCENE
}

\author{
Peter T. Soulé,${ }^{1,4}$ Paul A. Knapp, ${ }^{2}$ and Henri D. Grissino-Mayer ${ }^{3}$ \\ ${ }^{1}$ Department of Geography and Planning, Appalachian State University, Boone, North Carolina 28608 USA \\ ${ }^{2}$ Department of Anthropology and Geography, Georgia State University, Atlanta, Georgia 30303 USA \\ ${ }^{3}$ Department of Geography, The University of Tennessee, Knoxville, Tennessee 37996 USA
}

\begin{abstract}
Western juniper (Juniperus occidentalis var. occidentalis) is undergoing rapid rates of expansion, and human activities (domestic livestock grazing, fire suppression) are typically presented as the primary agents of change. To determine the importance of active disturbance as a vehicle for these major ecosystem changes (e.g., a near doubling of western juniper cover at some locales over a recent 30-yr period), we conducted a comparative study of western juniper establishment at matched disturbed and less-disturbed sites in Oregon (USA). We used dendroecological techniques to randomly sample and cross-date 160-200 trees per site from five Research Natural Areas (RNAs) or proposed RNAs, and from areas adjacent to these RNAs that are actively disturbed. For each location we determined the density of adult and juvenile western juniper and created a timeline of tree establishment. We discuss the probable causes of these establishment pattern changes. Recent increases in establishment could best be described as geometric on the disturbed sites. While trees on the less disturbed sites are generally older and have a more consistent establishment history, they also are experiencing increasing rates of establishment. Disturbance does appear to accelerate rates of establishment of western juniper, especially with domestic livestock grazing on sites that are downslope from established woodlands. Climatic changes, a lack of high-severity fires, an increasing seed rain, and atmospheric carbon dioxide enrichment are more recent causal mechanisms contributing to establishment. The driving forces proffered to explain the late 1800s to early 1900s pulse of establishment for western juniper (e.g., favorable climatic conditions, domestic livestock grazing) appear to be operative at the majority of our study sites. Conversely, a second pulse of establishment (post 1940s) occurred during a period that was not characterized by climatic conditions favorable for above-average radial growth of western juniper. Because our results show that rates of establishment are generally accelerating regardless of the disturbance regime, we suggest that active human disturbance is not a required element for these ecosystem changes to occur, and that other agents of change have either appeared or become more dominant in recent decades.
\end{abstract}

Key words: anthropogenic influences; Juniperus occidentalis; Pacific Northwest; western juniper; woodland expansion.

\section{INTRODUCTION}

Western juniper (Juniperus occidentalis var. occidentalis Hook.) is a tree species that has become increasingly invasive within sagebrush steppe of the interior Pacific Northwest (PNW) (Miller and Rose 1999). The core of its current range is central Oregon, but the species also exists in Washington, Idaho, California, and Nevada. It occupies part of the larger ( $\sim 29$ $\times 10^{6} \mathrm{ha}$ ) pinyon-juniper ecosystem of the American Southwest, Great Basin, and PNW (West 1999). Historically, western juniper was found primarily on rocky, upslope locations where it was able to avoid periodic wildfires (Burkhardt and Tisdale 1976). In lower elevations, it typically developed an open, savanna-like dispersal pattern (Sims Waichler et al. 2001).

Manuscript received 11 September 2002; revised 10 March 2003; accepted 23 April 2003; final version received 22 May 2003. Corresponding Editor: G. M. MacDonald.

${ }^{4}$ E-mail: soulept@appstate.edu
Increasing rates of establishment and a concurrent rapid expansion of the species during the last $150 \mathrm{yr}$ have been recorded at various locations (e.g., Miller and Wigand 1994, Miller and Rose 1995, Soulé and Knapp 2000, Wall et al. 2001). Rates of woodland establishment may follow several distinct patterns based on overstory canopy cover (Miller and Rose 1999). In open stands, geometric rates of establishment in the last 50 yr have been documented by Miller and Rose (1995) and Soulé and Knapp (2000), and recent inventories in central Oregon indicate that western juniper forests cover more than five times the area they did as recently as the mid 1930s (Gedney et al. 1999). The increases in cover and density of western juniper that have occurred in the last century are unique because they are occurring during an extended period of less than favorable climatic conditions (i.e., more arid; Miller and Wigand 1994). Pollen analysis has revealed that previous episodes of expansion typically occurred 
during periods with low evapotranspirational stresses (i.e., colder, wetter; Miller and Wigand 1994). Further, these increases are not unique to the Pacific Northwest as other western North American woodland species (e.g., pinyon [Pinus monophylla Torr. \& Frem.], Utah juniper [Juniperus osteosperma (Torr.) Little], redberry juniper [Juniperus pinchotti Sudw.], and honey mesquite [Prosopis glandulosa Torr.]) also have increased (e.g., McPherson et al. 1988, Archer 1994, Archer et al. 1995, Brown and Archer 1999, Ueckert et al. 2001). Questions therefore arise concerning the cause(s) for these expansions and whether the mechanisms responsible work over a broad geographic spatial scale.

Central to the issue of recent western juniper expansion is the role anthropogenic disturbances have played in potentially accelerating rates of establishment. By most accounts, western juniper began to establish more rapidly during the late 1800 s, a period of favorable climatic conditions that also witnessed the onset of significant domestic livestock grazing in the intermountain West (Miller and Wigand 1994). Domestic livestock grazing likely stimulated expansion of the species by two means. First, grazing results in a substantial decline in the amount of fine fuels needed to carry and sustain wildfires (Burkhardt and Tisdale 1976, Miller and Rose 1995, 1999). Second, grazing typically leads to an increase in shrubs that serve as host or nurse-plant sites for seedlings (West 1983, Eddleman 1987, Evans 1988). Subsequently, during a period when wetter than normal climatic conditions should have favored the development of large fires (i.e., the late 1800s), fire frequency was likely reduced by heavy domestic livestock grazing, allowing western juniper to establish (Miller and Rose 1999). With continued grazing and fire suppression efforts of the 20th century, the combined effects of reduced fire frequency and biological inertia (manifested through an increasing seed rain) may have been primary contributors to the increasing rates of establishment for this species. The effects of livestock grazing and/or altered fire regimes have been identified as the principal mechanisms for woodland invasion in other North American woodlands (Archer 1994, Brown and Archer 1999, Tausch and Nowak 1999). Thus, western juniper is not unique in its potential susceptibility to human influence.

Despite evidence pointing to the role of anthropogenic disturbance in facilitating the rapid expansion of western juniper, expansion also has been documented on sites that have a land use history of limited human impacts (Knapp and Soulé 1998, Soulé et al. 2003) and thus, the role of "other global change based drivers", (Tausch and Nowak 1999:77) should be explored. Recent studies have shown that seedlings of arid and semiarid woody species significantly benefit under higher atmospheric $\mathrm{CO}_{2}$ levels (Polley et al. 1999, Hamerlynck et al. 2000, Maherali and DeLucia 2000) because of increases in photosynthetic rates and/or greater drought tolerance. In addition, Bond and Midgley
(2000:865) have noted that elevated atmospheric $\mathrm{CO}_{2}$ may cause juvenile trees to grow more quickly, thus spending fewer years in the "topkill zone" where they are more vulnerable to periodic surface fires.

Because western juniper expansion apparently occurs on both heavily and minimally disturbed locations, another question arises concerning the types of disturbances that act as the agents stimulating such ecosystem changes. We hypothesize that western juniper establishment during the past $120 \mathrm{yr}$ has occurred under two different scenarios. The initial establishment phase was driven by the combined influences of favorable climatic conditions that coincided with reduced fire frequencies caused by extensive livestock grazing. The second establishment phase, particularly post-1950s, appears to be driven by mechanisms other than those traditionally cited, including atmospheric $\mathrm{CO}_{2}$, biological inertia, increasing annual temperature, and increasing summer precipitation. Given this, the primary objectives of our study are to (1) document the establishment history of western juniper on minimally disturbed areas in Oregon, (2) compare this with establishment histories on adjacent (disturbed) sites with similar physical characteristics, and (3) examine the suite of potential driving forces responsible for the temporal pattern of western juniper establishment. If, as is generally thought, active human disturbance is not a required element for expansion of this tree species, then decisions and criteria used by the Bureau of Land Management, U.S. Forest Service, and others to manage western juniper woodlands may need to be re-evaluated.

\section{Methods \\ Site selection}

We selected five matched pairs of study sites in central Oregon (Fig. 1) that represent western juniper growth under a diverse range of physical characteristics (e.g., slope, elevation, soil characteristics, climate; Table 1). Each matched pair included a site that is recognized by the Bureau of Land Management or the U.S. Forest Service as a Research Natural Area (RNA) or proposed RNA (PRNA). These three RNAs and two PRNAs are atypical of central Oregon rangelands because their land use history includes minimal anthropogenic disturbances (e.g., livestock grazing, wood cutting). At Powell Butte RNA (PBU), Sutton Mountain (STU), and Haystack Butte (HBU), the primary factor limiting disturbance is topography. The steep, rocky slopes and a paucity of grasses either preclude or limit grazing. The other two sites, Benjamin RNA (BNU) and Goodlow Mountain RNA (GMU), are fenced exclosures where domestic livestock grazing has been eliminated (1984 for BNU, 1942 for GMU), and grazing history prior to fencing was minimal (Table 1). Exotic species (e.g., cheatgrass [Bromus tectorum L.]) at all low-impact sites were either absent or sparse, 


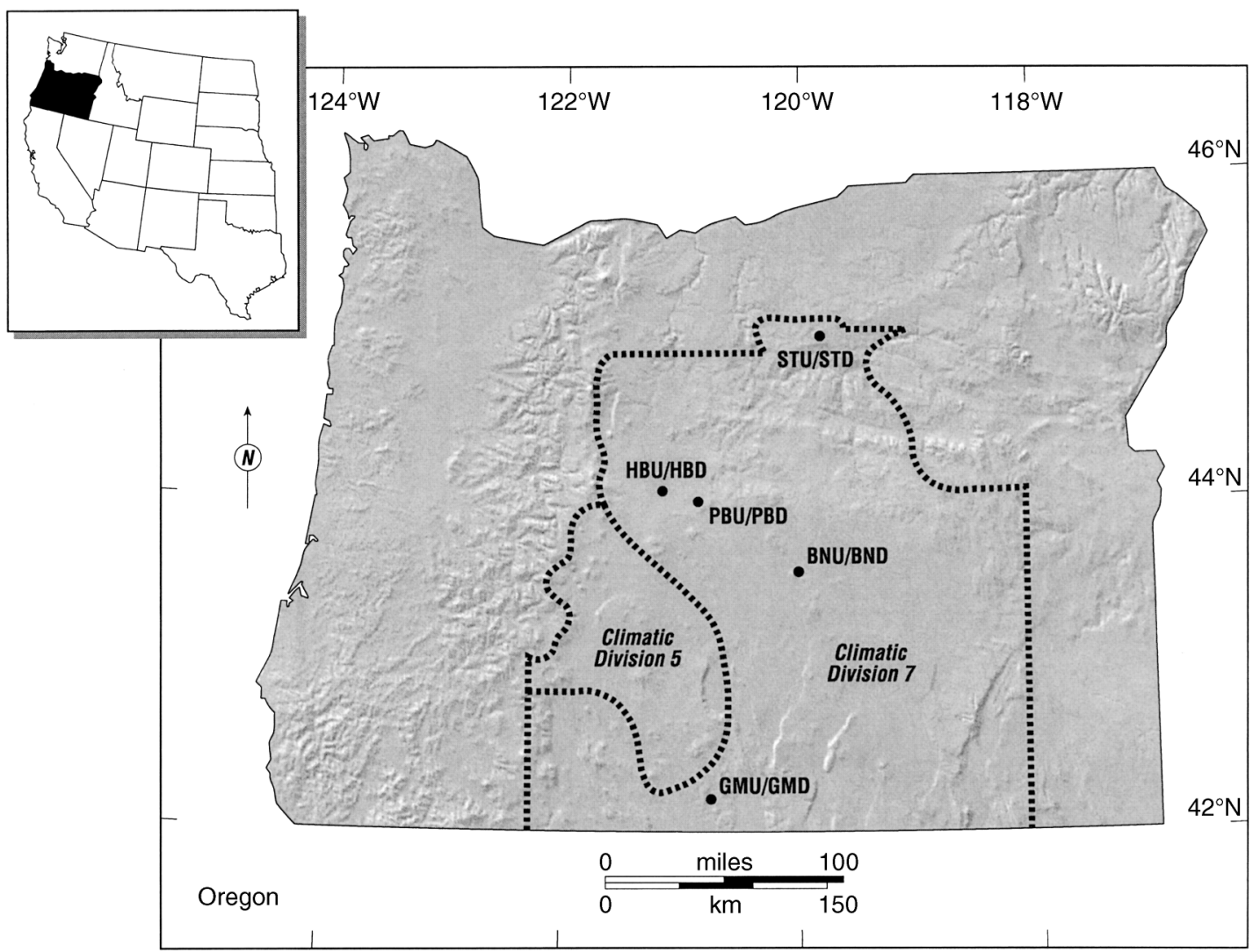

FIG. 1. Location of study sites and boundaries for Climatic Divisions 5 and 7.

an unusual characteristic for woodland-steppe environments in the intermountain West, and one of the criteria we used for site selection. Because of the relatively minimal human effects, the establishment history of western juniper on these sites is as close to representing that which would have occurred in the absence of human activities as we may find within the range for this species.

The matched sites for each of these minimally disturbed areas are adjacent sites with similar soil characteristics, plant associations, climate, aspect, and slope that have had a more typical human disturbance regime (Table 1). At each of the more disturbed sites (BND, PBD, STD, HBD, GMD), we found evidence of active grazing (e.g., livestock dung and hoof prints), and some sites had other indicators of more active disturbance (e.g., abundant cheatgrass, cattle trails, and abandoned roads). The PBD, STD, and HBD sites were all established downslope from their less-disturbed matched pairs, while GMD and BND were established outside the fenced boundary of the RNAs.

\section{Field methods}

At each of the study sites, we established five plot centers at $150-\mathrm{m}$ intervals along a transect that followed a surface contour and had a randomly chosen starting point. At a distance of $50 \mathrm{~m}$ from each plot center, we placed a 0.05 -ha circular plot at vectors 0 , 90,180 , and 270 degrees, for a total of 20 plots along the transect. The only exception was at HBU, where it was only possible to place 16 plots in terrain that was minimally disturbed. We used these plots to determine the density of mature and juvenile western juniper and for dendroecological sampling. We counted an individual as a juvenile if it was $<1.25 \mathrm{~m}$ in height and displayed either full needle foliage, or a mixed foliage of needles and awls typical of juveniles. All other individuals were counted as adults.

The center of each 0.05 -ha plot was used to randomly sample 200 live western junipers per site (160 trees at $\mathrm{HBU}$ ) using the 10 trees closest to the center point of each 0.05-ha plot. For adult trees with a sufficient basal diameter to allow for nondestructive sampling (a requirement mandated by the Bureau of Land Management and U.S. Forest Service within the boundaries of the protected study areas), we obtained two increment cores as low on the tree bole as possible (mean height of sampling was $30 \mathrm{~cm}$ ). For juveniles, we recorded the height of each individual and the location where each was found using categories similar to those employed by Miller and Rose (1995): (1) canopy (individual was found underneath the canopy of a live western juniper), (2) shrub (individual was found underneath the canopy of a live shrub), (3) grass (individual 
TABle 1. Physical characteristics, fire and disturbance history, and plant association at the 10 study sites.

\begin{tabular}{|c|c|c|c|c|c|c|c|}
\hline Site & $\begin{array}{l}\text { Latitude (N), } \\
\text { longitude (W) }\end{array}$ & $\begin{array}{l}\text { Mean } \\
\text { elevation } \\
(\mathrm{m})\end{array}$ & $\begin{array}{l}\text { Slope } \\
\text { (de- } \\
\text { grees) }\end{array}$ & $\begin{array}{l}\text { Soil type and/or } \\
\text { description } \dagger\end{array}$ & Fire history $\ddagger$ & $\begin{array}{l}\text { Disturbance } \\
\text { history }\end{array}$ & Plant association $\S$ \\
\hline$\overline{\mathrm{BNU}}$ & $43^{\circ} 35^{\prime}, 120^{\circ} 21^{\prime}$ & 1510 & $1-2$ & $\begin{array}{l}\text { Beden-Ninemile; } \\
\text { shallow, stony, } \\
\text { sandy loams }\end{array}$ & $\begin{array}{l}\text { No recorded fires } \\
\text { 1968-1998; } \\
\text { field reconnais- } \\
\text { sance shows } \\
\text { evidence of } \\
\text { isolated fires } \\
\text { that have not } \\
\text { spread. }\end{array}$ & $\begin{array}{l}\text { Exclosure was } \\
\text { completed in } \\
1984 ; \text { light } \\
\text { grazing prior to } \\
1984 .\end{array}$ & $\begin{array}{l}\text { Juniperus occi- } \\
\text { dentalis/Festu- } \\
\text { ca idahoensis }\end{array}$ \\
\hline BND & $43^{\circ} 35^{\prime}, 120^{\circ} 20^{\prime}$ & 1510 & $1-2$ & $\begin{array}{l}\text { Beden-Ninemile; } \\
\text { shallow, stony, } \\
\text { sandy loams }\end{array}$ & $\begin{array}{l}\text { No recorded fires } \\
\text { 1968-1998; } \\
\text { field reconnais- } \\
\text { sance shows } \\
\text { evidence of } \\
\text { isolated fires } \\
\text { that have not } \\
\text { spread. }\end{array}$ & $\begin{array}{l}\text { Field reconnais- } \\
\text { sance shows } \\
\text { evidence of ac- } \\
\text { tive grazing } \\
\text { (manure, hoof } \\
\text { prints). }\end{array}$ & $\begin{array}{l}\text { Juniperus occi- } \\
\text { dentalis/Festu- } \\
\text { ca idahoensis }\end{array}$ \\
\hline GMU & $42^{\circ} 13^{\prime}, 121^{\circ} 11^{\prime}$ & 1524 & $1-2$ & $\begin{array}{l}\text { moderately deep, } \\
\text { stony colluvi- } \\
\text { um }\end{array}$ & $\begin{array}{l}\text { There were recent } \\
\text { prescribed } \\
\text { burns in a near- } \\
\text { by ponderosa } \\
\text { pine (Pinus } \\
\text { ponderosa) } \\
\text { ecotone, but } \\
\text { these fires had } \\
\text { not carried onto } \\
\text { the site. }\end{array}$ & $\begin{array}{l}\text { Exclosure was } \\
\text { completed in } \\
\text { 1942; light } \\
\text { grazing prior to } \\
1942 \text {. }\end{array}$ & $\begin{array}{l}\text { Juniperus occi- } \\
\text { dentalis/Artemi- } \\
\text { sia tridentatal } \\
\text { Festuca ida- } \\
\text { hoensis }\end{array}$ \\
\hline GMD & $42^{\circ} 13^{\prime}, 121^{\circ} 10^{\prime}$ & 1500 & $1-4$ & $\begin{array}{l}\text { moderately deep, } \\
\text { stony colluvi- } \\
\text { um }\end{array}$ & $\begin{array}{l}\text { There were recent } \\
\text { prescribed } \\
\text { burns in a near- } \\
\text { by ponderosa } \\
\text { pine (Pinus } \\
\text { ponderosa) } \\
\text { ecotone, but } \\
\text { these fires had } \\
\text { not carried onto } \\
\text { the site. }\end{array}$ & $\begin{array}{l}\text { Grazing is active, } \\
\text { but very light } \\
\text { (manure and } \\
\text { hoof prints are } \\
\text { scarce). }\end{array}$ & $\begin{array}{l}\text { Juniperus occi- } \\
\text { dentalis/Artemi- } \\
\text { sia tridentatal } \\
\text { Festuca ida- } \\
\text { hoensis }\end{array}$ \\
\hline $\mathrm{HBU}$ & $44^{\circ} 27^{\prime}, 121^{\circ} 09^{\prime}$ & 1185 & $30-44$ & $\begin{array}{l}\text { Lickskillit-Red- } \\
\text { cliff; well- } \\
\text { drained, thin, } \\
\text { very gravelly } \\
\text { loams }\end{array}$ & $\begin{array}{l}\text { Very rocky and } \\
\text { sparse cover } \\
\text { with no evi- } \\
\text { dence of wide- } \\
\text { spread fire. }\end{array}$ & $\begin{array}{l}\text { Slope steepness } \\
\text { and loose rocks } \\
\text { preclude live- } \\
\text { stock grazing. }\end{array}$ & $\begin{array}{l}\text { Juniperus occi- } \\
\text { dentalis/Artemi- } \\
\text { sia tridentatal } \\
\text { Festuca ida- } \\
\text { hoensis }\end{array}$ \\
\hline HBD & $44^{\circ} 27^{\prime}, 121^{\circ} 09^{\prime}$ & 1065 & $2-20$ & $\begin{array}{l}\text { Lickskillit-Red- } \\
\text { cliff; well- } \\
\text { drained, thin, } \\
\text { very gravelly } \\
\text { loams }\end{array}$ & $\begin{array}{l}\text { There was a large } \\
\text { prescribed burn } \\
\text { in the area in } \\
\text { 1982, but our } \\
\text { sampling tran- } \\
\text { sect avoided } \\
\text { the burned } \\
\text { area. }\end{array}$ & $\begin{array}{l}\text { There is plentiful } \\
\text { evidence of } \\
\text { grazing (cow } \\
\text { trails, manure, } \\
\text { hoof prints). } \\
\text { An older vehi- } \\
\text { cle trail dissect- } \\
\text { ed the sampling } \\
\text { transect. }\end{array}$ & $\begin{array}{l}\text { Juniperus occi- } \\
\text { dentalis/Artemi- } \\
\text { sia tridentatal } \\
\text { Festuca ida- } \\
\text { hoensis }\end{array}$ \\
\hline PBU & $44^{\circ} 09^{\prime}, 121^{\circ} 00^{\prime}$ & 1220 & $5-25$ & $\begin{array}{l}\text { Tristan and Ana- } \\
\text { tone-Tuscor; } \\
\text { well-drained, } \\
\text { cobbley loams }\end{array}$ & $\begin{array}{l}\text { No recorded fires } \\
\text { 1968-1998; } \\
\text { field reconnais- } \\
\text { sance shows } \\
\text { evidence of } \\
\text { isolated fires } \\
\text { that have not } \\
\text { spread. }\end{array}$ & $\begin{array}{l}\text { Domestic live- } \\
\text { stock grazing is } \\
\text { limited due to } \\
\text { slope steepness } \\
\text { and rocky ter- } \\
\text { rain. }\end{array}$ & $\begin{array}{l}\text { Juniperus occi- } \\
\text { dentalis/Artemi- } \\
\text { sia tridentatal } \\
\text { Festuca ida- } \\
\text { hoensis }\end{array}$ \\
\hline PBD & $44^{\circ} 09^{\prime}, 121^{\circ} 01^{\prime}$ & 1145 & $5-20$ & $\begin{array}{l}\text { Tristan and Ana- } \\
\text { tone-Tuscor; } \\
\text { well-drained, } \\
\text { cobbley loams }\end{array}$ & $\begin{array}{l}\text { No recorded fires } \\
\text { 1968-1998; } \\
\text { field reconnais- } \\
\text { sance shows } \\
\text { evidence of } \\
\text { isolated fires } \\
\text { that have not } \\
\text { spread. }\end{array}$ & $\begin{array}{l}\text { Grazing is active } \\
\text { (manure, hoof } \\
\text { prints), with } \\
\text { grazing allot- } \\
\text { ments up to } \\
200 \text { head. }\end{array}$ & $\begin{array}{l}\text { Juniperus occi- } \\
\text { dentalis/Artemi- } \\
\text { sia tridentatal } \\
\text { Festuca ida- } \\
\text { hoensis }\end{array}$ \\
\hline
\end{tabular}


TABle 1. Continued.

\begin{tabular}{|c|c|c|c|c|c|c|c|}
\hline Site & $\begin{array}{l}\text { Latitude (N), } \\
\text { longitude (W) }\end{array}$ & $\begin{array}{l}\text { Mean } \\
\text { elevation } \\
\text { (m) }\end{array}$ & $\begin{array}{l}\text { Slope } \\
\text { (de- } \\
\text { grees) }\end{array}$ & $\begin{array}{l}\text { Soil type and/or } \\
\text { description } \dagger\end{array}$ & Fire history & $\begin{array}{c}\text { Disturbance } \\
\text { history } \neq\end{array}$ & Plant association $\S$ \\
\hline STU & $44^{\circ} 41^{\prime \prime}, 120^{\circ} 14^{\prime}$ & 800 & $16-40$ & $\begin{array}{l}\text { Gwin; well- } \\
\text { drained, shallow, } \\
\text { very stony clay } \\
\text { loams }\end{array}$ & $\begin{array}{l}\text { No recorded fires } \\
\text { 1968-1998; field } \\
\text { reconnaissance } \\
\text { shows evidence } \\
\text { of isolated fires } \\
\text { that have not } \\
\text { spread. }\end{array}$ & $\begin{array}{l}\text { Sheep grazed in } \\
\text { the region from } \\
\text { the late } 1800 \mathrm{~s} \\
\text { until } 1940 \mathrm{~s} \text {. } \\
\text { Slope steepness } \\
\text { limits or pre- } \\
\text { cludes domestic } \\
\text { livestock } \\
\text { grazing. }\end{array}$ & $\begin{array}{l}\text { Juniperus occi- } \\
\text { dentalis/Artemi- } \\
\text { sia arbusculal } \\
\text { Agropyron spi- } \\
\text { catum }\end{array}$ \\
\hline STD & $44^{\circ} 41^{\prime}, 120^{\circ} 15^{\prime}$ & 730 & $5-20$ & $\begin{array}{l}\text { Simas; well- } \\
\text { drained, shallow, } \\
\text { very stony clay } \\
\text { loams }\end{array}$ & $\begin{array}{l}\text { No recorded fires } \\
\text { 1968-1998; } \\
\text { field reconnais- } \\
\text { sance shows } \\
\text { evidence of } \\
\text { isolated fires } \\
\text { that have not } \\
\text { spread. }\end{array}$ & $\begin{array}{l}\text { There is plentiful } \\
\text { evidence of } \\
\text { active grazing } \\
\text { (cow trails, } \\
\text { manure, hoof } \\
\text { prints) and } \\
\text { some evidence } \\
\text { of (older) cutting } \\
\text { for fence posts } \\
\text { (i.e., cut limbs). }\end{array}$ & $\begin{array}{l}\text { Juniperus occi- } \\
\text { dentalis/Artemi- } \\
\text { sia arbusculal } \\
\text { Agropyron spi- } \\
\text { catum }\end{array}$ \\
\hline
\end{tabular}

Note: Sites are Benjamin undisturbed (BNU) and disturbed (BND), Goodlow Mountain undisturbed (GMU) and disturbed (GMD), Haystack Butte undisturbed (HBU) and disturbed (HBD), Powell Butte undisturbed (PBU) and disturbed (PBD), and Sutton Mountain undisturbed (STU) and disturbed (STD).

$\dagger$ Soil information is from the National Cooperative Soil Survey, U.S. Department of Agriculture.

$\$$ Fire and disturbance history of sites was compiled through interviews with Bureau of Land Management and U.S. Forest Service personnel and through our on-site reconnaissance.

$\S$ Plant association information is from Natural Heritage Advisory Council to the State Land Board (1998) and confirmed by field observations.

was growing within a clump of grass), (4) interspace/ rock (the individual was growing in the open, or in space underneath a rock overhang).

\section{Core processing, age determination, and} development of tree-ring index chronologies

All core samples were glued to wooden core mounts, sanded with progressively finer grit sandpaper to reveal the cellular structure of the tree rings, and then crossdated using skeleton plots (Stokes and Smiley 1996) and list method techniques (Yamaguchi 1991). Precision of cross-dating was verified statistically by measuring selected cores and processing the measurement series using the quality-control program COFECHA (Holmes 1983, Grissino-Mayer 2001). When a core sample did not include the pith, but curvature was present, we used pith locators to estimate the number of rings present to the pith (Applequist 1958), and adjusted the ages of the trees accordingly.

At each of the five matched-pair sites, we additionally collected 45 whole-sample juveniles with heights ranging from $1 \mathrm{~cm}$ (seedlings, identified as first year growth when the cotyledon was still attached) to 100 $\mathrm{cm}$ on land adjacent to, but outside, the boundaries of protected areas. We used these samples to develop regression models predicting age as a function of height. After recording the height, the juvenile was cut at ground level and dated using standard cross-dating procedures (i.e., skeleton plots, list method) to determine the year of establishment. Despite the presence of sig- nature years (e.g., 1992) near the end of the record for each chronology, we must characterize the dating of some of our youngest samples as ring counting instead of cross-dating, due to the lack of multiple marker years. We experimented with linear and nonlinear regression models and selected the functional form that best fit the distribution at each site. We examined the Studentized residuals and Cook's $d$ statistic for each observation to identify outliers that significantly and adversely affected the regression models and removed them, when necessary (Schlotzhauer and Littell 1986). We then used the age-height models to determine the age of trees that could not be cored, and to determine the number of years of growth that had elapsed before a tree reached the height at which it was cored. Our use of nonlinear, site-specific, age-height regression models coupled with a low coring height (mean of 30 $\mathrm{cm}$ ) offers a high level of precision for the nondestructive sampling techniques we were required to use. By comparison, other studies of western juniper establishment have used less precise methods (e.g., Miller and Rose 1995, Soulé and Knapp 2000). Despite our care to be as exact as possible, four aspects of the methods impart error into the determination of the actual year of establishment for each tree. These are (1) the use of imperfect regression models to adjust tree age, (2) the use of pith locators on some core samples, (3) sampling juveniles at ground level instead of the root/shoot interface (Telewski 1993), and (4) the lack of multiple 
TABle 2. Age/height regression models used to date juveniles and to adjust the final age of cored trees according to the height at which the core sample was extracted.

\begin{tabular}{|c|c|c|c|c|}
\hline Site and regression model & $F$ & $R^{2}$ & $n$ & $\begin{array}{c}\text { Standard } \\
\text { error }\end{array}$ \\
\hline \multicolumn{5}{|l|}{ BNU/BND } \\
\hline Age $=0.4654\left(\right.$ Height $\left.^{1.2031}\right)$ & $188.24 * *$ & 0.83 & 41 & 0.539 \\
\hline \multicolumn{5}{|l|}{ GMU/GMD } \\
\hline Age $=0.2008\left(\right.$ Height $\left.^{1.1664}\right)$ & $345.15 * *$ & 0.89 & 44 & 0.513 \\
\hline \multicolumn{5}{|l|}{ HBU/HBD } \\
\hline Age $=0.225\left(\right.$ Height $\left.^{1.0816}\right)$ & $273.88 * *$ & 0.87 & 43 & 0.529 \\
\hline \multicolumn{5}{|l|}{$\mathrm{PBU} / \mathrm{PBD}$} \\
\hline Age $=-2.01+1.193($ Height $)-0.0098\left(\right.$ Height $\left.^{2}\right)+0.0000282\left(\right.$ Height $\left.^{3}\right)$ & $97.8 * *$ & 0.88 & 43 & 5.246 \\
\hline \multicolumn{5}{|l|}{ STU/STD } \\
\hline Age $=0.2152\left(\right.$ Height $\left.^{1.2032}\right)$ & $228.08 * *$ & 0.84 & 44 & 0.616 \\
\hline
\end{tabular}

marker years in the youngest individuals in the samples used to develop the age/height regression models.

To examine the establishment history, we plotted the percentage of dateable trees established in each year, beginning with AD 1500 . Only HBU (8.6\% of the sample) had a substantial number of trees establishing prior to 1500 . BND, GMU, and PBU had $0.7 \%, 1.1 \%$, and $0.6 \%$ of the sample establishing prior to 1500 , respectively; all other sites had $0 \%$. Thus, we begin the timeline graphs of tree establishment at 1500 . Plotting percent established vs. the actual number of trees established per year was necessary because it was not possible to obtain an establishment date for every individual, resulting in a variable sample size among sites. In some cases, we obtained multiple core samples from a tree, but were unable to reach the tree center because of heart rot that had destroyed the inner portions of the tree. Accordingly, these trees were excluded from our analysis of establishment. However, because the heart rot affecting western juniper typically occurs somewhere between 1730 and 1750 (Knapp and Soulé 1999), the elimination of these trees primarily affects our establishment patterns only prior to 1750 . Additionally, we were unable to accurately cross-date some cores because the core was damaged or the ring structure was unclear. These samples also were eliminated from this analysis. Such problematic cores, however, represent only $12.2 \%$ of our overall sample size.

To help determine whether periods of establishment were concurrent with periods of enhanced radial growth, we developed tree-ring index chronologies for each site. From our core samples, we selected a subset of individuals with the longest, clearest ring sequences for measurement. Using the computer program ARSTAN (Cook 1985), we assembled a standard index chronology for each site (Fritts 2001) using conservative standardization techniques (i.e., negative ex- ponential curves or trend lines) to ensure preservation of necessary low-frequency, long-term trends (Briffa et al. 1996, Grissino-Mayer 1996).

\section{Climate and radial growth analyses}

To identify prospective climatic variables associated with establishment, we initially conducted Spearman rank correlation analyses (including up to 10-yr lags) between the percentage of trees established in any given year at each site and a suite of climatic variables over a common period (1896-1998) that corresponded to the instrumental climate record. We examined monthly, seasonal, and annual (including growing season, i.e., July of the previous year to August of the current year) values of precipitation, temperature, and, to account for the potential effects of temperature and evapotranspiration, the Palmer Drought Severity Index (PDSI; Palmer 1965) using climatic division-level data (all sites compared to Division 7, GMU/GMD also compared to Division 5 records due to its close proximity) (Fig. 1). For the climatic variables exhibiting significant relationships that were evident at multiple sites and/or over multiple years (i.e., the lagged correlations), we then calculated decadal means (using Climatic Division 7 data only as all sites are within its boundaries), converted these to standardized scores, and used Spearman rank correlation and selected graphs to compare them to decadal standardized scores of establishment after first combining the five less disturbed samples into one larger data set and the five disturbed samples into another and recalculating the percentage of trees that established in any given year. The aggregation of data from yearly values to decadal means was necessary because the techniques we used to determine year of establishment for each individual sampled are imperfect (e.g., regression model error, Table 2). 
TABLE 3. Information on western juniper at each study site and mean conditions at all less-disturbed and disturbed sites.

\begin{tabular}{|c|c|c|c|c|c|c|c|c|c|c|}
\hline \multirow[b]{3}{*}{ Site } & \multirow{2}{*}{\multicolumn{3}{|c|}{$\begin{array}{c}\text { Density and } \\
\text { adult-to-juvenile ratio }\end{array}$}} & \multirow{2}{*}{\multicolumn{3}{|c|}{$\begin{array}{l}\text { Berry production on } \\
\text { adult trees }\end{array}$}} & \multicolumn{4}{|c|}{ Juvenile location } \\
\hline & & & & & & & \multirow{2}{*}{$\begin{array}{c}\text { Within } \\
\text { canopy } \\
(\%)\end{array}$} & \multirow{2}{*}{$\begin{array}{c}\text { Within } \\
\text { shrubs } \\
(\%)\end{array}$} & \multirow{2}{*}{$\begin{array}{c}\text { Within } \\
\text { grasses } \\
(\%)\end{array}$} & \multirow[b]{2}{*}{$\begin{array}{c}\text { Interspace/ } \\
\text { rock }(\%)\end{array}$} \\
\hline & $\begin{array}{l}\text { No. } \\
\text { trees/ha }\end{array}$ & $\begin{array}{l}\text { Juvenile } \\
(\%)\end{array}$ & $\begin{array}{l}\text { Adult } \\
(\%)\end{array}$ & $\begin{array}{l}\text { Copious } \\
(\%)\end{array}$ & $\begin{array}{c}\text { Absent } \\
(\%)\end{array}$ & $\begin{array}{l}\text { Mixed } \\
(\%)\end{array}$ & & & & \\
\hline $\mathrm{BNU}$ & 118 & 70 & 30 & 7 & 49 & 44 & 20 & 33 & 35 & 12 \\
\hline BND & 190 & 63 & 37 & 7 & 38 & 55 & 21 & 52 & 16 & 11 \\
\hline GMU & 110 & 34 & 66 & 11 & 62 & 27 & 15 & 7 & 0 & 78 \\
\hline GMD & 91 & 41 & 59 & 5 & 52 & 43 & 0 & 6 & 1 & 93 \\
\hline HBU & 88 & 27 & 73 & 12 & 41 & 47 & 24 & 10 & 4 & 62 \\
\hline HBD & 544 & 68 & 32 & 0 & 43 & 57 & 43 & 22 & 4 & 31 \\
\hline PBU & 222 & 46 & 54 & 34 & 23 & 43 & 54 & 10 & 27 & 9 \\
\hline PBD & 427 & 60 & 40 & 17 & 24 & 59 & 56 & 20 & 14 & 10 \\
\hline STU & 138 & 40 & 60 & 8 & 68 & 24 & 53 & 10 & 17 & 20 \\
\hline STD & 213 & 32 & 68 & 10 & 66 & 24 & 62 & 19 & 4 & 15 \\
\hline All less-disturbed sites & 135.2 & 43.4 & 56.6 & 14.4 & 48.6 & 37.0 & 33.2 & 14.0 & 16.6 & 36.2 \\
\hline All disturbed sites & 293.0 & 52.8 & 47.2 & 7.8 & 44.6 & 47.6 & 36.4 & 23.8 & 7.8 & 32.0 \\
\hline All sites & 214.1 & 48.1 & 51.9 & 11.1 & 46.6 & 42.3 & 34.8 & 18.9 & 12.2 & 34.1 \\
\hline
\end{tabular}

Note: Sites are Benjamin undisturbed (BNU) and disturbed (BND), Goodlow Mountain undisturbed (GMU) and disturbed (GMD), Haystack Butte undisturbed (HBU) and disturbed (HBD), Powell Butte undisturbed (PBU) and disturbed (PBD), and Sutton Mountain undisturbed (STU) and disturbed (STD).

For each study site, we graphically examined the relationships between percentage of trees established in any given year and the site-specific tree-ring index (a measurement of standardized radial growth) to help determine whether environmental conditions conducive to enhanced radial growth could also produce enhanced periods of establishment. Because some core samples used for chronology development may have not had a determinable interior date, or trees in the establishment timeline may not have been selected for chronology development, the timelines for radial growth may be shorter or longer than the establishment timelines. We also compared establishment to radial growth using rank correlation of decadal means. For consistency, we used the same period (1896-1998) as the climate analyses.

\section{Tests for possible establishment mechanisms}

To assess the possible role of livestock grazing on establishment, and to test the degree of similarity between upslope and downslope locations, we calculated the mean age of trees for the disturbed sites and compared them to the mean age of trees for the undisturbed sites using a Wilcoxon signed-rank test (Burt and Barber 1996). Additionally, we examined the ratio of juvenile to adult western juniper at each site to determine whether a given study site had characteristics of an emerging vs. established woodland.

\section{RESUlts}

Four of the five regression models used to date juvenile trees (and to adjust the final establishment age to account for the height at which core samples were taken) are power function in form, while the other is cubic (Table 2). All power function models had positively heteroscedastic residuals (i.e., increasing variance as height increased), while the cubic model for
PBU/PBD had homoscedastic residuals (i.e., stable variance as height increased). Thus, the level of error at the mean coring height $(30 \mathrm{~cm})$ was generally less than that for the entire model.

While there is a slightly greater juvenile to adult ratio on the disturbed sites, no clear intersite pattern emerged (Table 3). Juvenile western junipers were predominately found within the canopy of an existing tree or within a host shrub (53.7\% occurrence). One notable difference in juvenile location was that individuals were more likely to be found within a shrub canopy and less likely to be found within grasses on the disturbed sites compared to less disturbed sites.

The maximum number of trees established in any given year at BNU was $4.0 \%$ (1921, 1934; Fig. 2). Growth index values revealed that the period of lowest sustained growth (the 1930s) corresponds to the period of greatest establishment, but that the most recent pulse of establishment occurred during a period of generally enhanced growth. Compared to BND, the pattern of establishment at BNU is more even aged until the spike of establishment beginning in the late 1950s. Sixty-two percent of the trees established between 1959 and 1998 at BND compared to $39 \%$ over the same period at BNU. Although significantly different $(P<0.05)$, the mean age of trees at BND is only slightly younger (65 yr) than at BNU (68 yr) (Table 4). The only clear relationship between growth and establishment at BND occurs post 1950, when both measures trend upward.

Patterns of establishment at GMU and GMD (Fig. 3 ) are closely matched. While the peak of establishment is slightly later at GMD (4.1\% in 1963) than at GMU (3.3\% in 1946), both sites retain high levels of establishment through the early 1990s. At both locations, the initial pulse of establishment (late 1800s/early 1900s) occurred near the end of a sustained period of increasing growth, but the peak of establishment oc- 


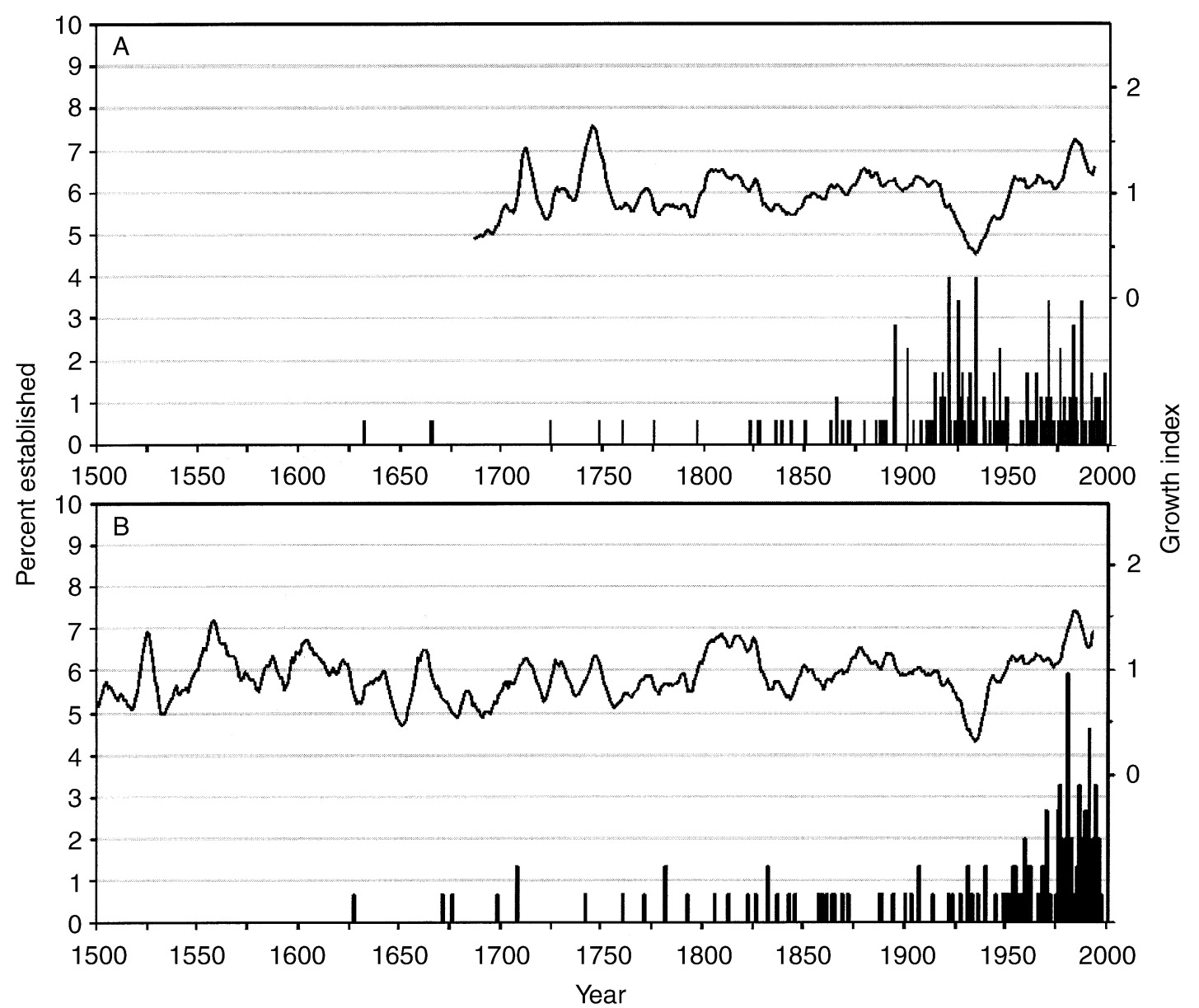

FIG. 2. Percentage of western juniper established per year (vertical bars), and 11-yr running mean of radial growth (solid line) for (A) BNU and (B) BND.

curred during a period of near average growth (i.e., growth index values near 1.0).

The greatest contrast in establishment history among the five matched pairs occurs between HBU and HBD (Fig. 4). While there is a slight increase in the rate of establishment during the last $20 \mathrm{yr}$, HBU exhibits the most even-aged pattern of establishment among the 10 study sites. The HBU sample also contains the oldest tree (established AD 1235), and has the oldest mean age of trees among the 10 study sites (Table 4). While the first pulse of establishment at HBD occurred from the early 1900 s to the late 1930 s, the majority of trees (61\%) established during the last 20 sample years. Although decreasing and generally below-average growth coincided with the first pulse of establishment at HBD, the most recent pulse occurred during a period of increasing and above-average growth.

Only subtle differences in the establishment history are evident between PBU and PBD (Fig. 5). Both have an initial pulse of sustained establishment beginning in the late $1800 \mathrm{~s}$, but more trees established at PBU during this period (23.7\% from 1890 to 1930 at PBU compared to $20.2 \%$ at PBD). The greatest differences occurred in the last two decades, with $39.9 \%$ of the trees establishing between 1980 and 1998 at PBD compared to $24.3 \%$ at PBU. At PBD, the pulse of establishment beginning in the late 1800s was preceded by several decades of generally increasing, but often below-average growth, and the gap in establishment during the 1930s and early 1940 s corresponds to a period of well below-average growth.

Although a similar pattern of establishment exists for STU and STD (Fig. 6), the STU sample is significantly older (Table 4), with more trees establishing during the 1700s and early-to-mid 1800s, and less in the last two decades $(28.7 \%$ established between 1980 and 1999 at STU, 36.7\% for STD). At both sites, a short-lived but substantial growth spike in the late 1970 s to early 1980 s preceded the final large pulse of establishment.

The primary similarity in both less-disturbed and disturbed sites is an initial sustained pulse of establishment beginning in the late 1800 s to early 1900 s that peaked in the 1920s (Fig. 7). This pulse began about 
TABLE 4. Comparison of mean ages of western juniper between disturbed and less-disturbed sites.

\begin{tabular}{|c|c|c|c|c|}
\hline $\begin{array}{l}\text { Site } \\
\text { compar- } \\
\text { ison }\end{array}$ & $\begin{array}{c}\text { Sample } \\
\text { size }\end{array}$ & $\begin{array}{c}\text { Mean } \\
\text { age (yr) }\end{array}$ & $\begin{array}{l}\text { Standard } \\
\text { deviation }\end{array}$ & $\begin{array}{l}\text { Wilcoxon } \\
\text { test } P \text { value }\end{array}$ \\
\hline \multicolumn{5}{|c|}{ Upslope/downslope sites } \\
\hline $\mathrm{HBU}$ & 105 & 211 & 186.9 & \multirow{2}{*}{$\rightarrow 0.000$} \\
\hline HBD & 200 & 30 & 33.9 & \\
\hline PBU & 173 & 70 & 79.6 & \multirow{2}{*}{$\rightarrow 0.007$} \\
\hline PBD & 183 & 55 & 68.7 & \\
\hline STU & 188 & 89 & 82.6 & \multirow[t]{2}{*}{$\rightarrow 0.009$} \\
\hline STD & 188 & 63 & 57.5 & \\
\hline \multicolumn{5}{|c|}{ Exclosures } \\
\hline $\mathrm{BNU}$ & 176 & 68 & 61.8 & \multirow[t]{2}{*}{$\rightarrow 0.001$} \\
\hline BND & 152 & 65 & 92.6 & \\
\hline GMU & 183 & 65 & 82.0 & \multirow[t]{2}{*}{$\rightarrow 0.817$} \\
\hline GMD & 173 & 62 & 57.8 & \\
\hline
\end{tabular}

Note: Sites are Benjamin undisturbed (BNU) and disturbed (BND), Goodlow Mountain undisturbed (GMU) and disturbed (GMD), Haystack Butte undisturbed (HBU) and disturbed (HBD), Powell Butte undisturbed (PBU) and disturbed (PBD), and Sutton Mountain undisturbed (STU) and disturbed (STD).

a decade earlier at the less-disturbed sites (1890-1900 compared to 1900-1910 at the disturbed sites). While both less-disturbed and disturbed sites showed a downturn in establishment following the drought of the 1930s, the reductions are more evident on the disturbed sites. After 1900, the establishment history of the disturbed sites was more episodic and pronounced than that observed on the less disturbed sites. On the less disturbed sites, $12.0 \%$ of the sample established prior to 1800 and $21.9 \%$ from 1980 to 1999 . For the disturbed sites, only $4.6 \%$ of the sample established prior to 1800 and $39.3 \%$ post- 1980 . In general, the establishment history of the less-disturbed sites is older and shows more consistent increases through time than on the disturbed sites. Recent increases in establishment on the disturbed sites are geometric.

From the decadal correlation analyses, only total summer (June through August) precipitation, annual temperature, and summer temperature are significantly $(P<0.05)$ related to establishment at either the combined disturbed or less-disturbed sites (Table 5). The positive covariance of these variables is confirmed graphically (Fig. 8). Using yearly data from 18961998 , significant $(P<0.05)$ and positive trends were found for total summer precipitation (June through August) and annual temperature.

Although enhanced growth of western juniper is positively related with winter/spring precipitation (Knapp et al. 2001a), this climate variable has no relationship to establishment (Table 5). Further, the only significant
$(P<0.05)$ relationship between radial growth and establishment from the decadal analyses was for BND $\left(r_{\mathrm{s}}\right.$ $=0.825)$.

\section{DISCUSSION}

Our results show increasing rates of establishment, and are in agreement with studies that have addressed the issue of 20th-century western juniper expansion on disturbed locations (Burkhardt and Tisdale 1976, Young and Evans 1981, Edleman 1987, Miller and Rose 1995). Further, our results support the prior results that rates of afforestation of this species can increase even in the absence of significant direct human disturbances, such as domestic livestock grazing. Repeat aerial photography analyses at four of the five matched study sites (all except BNU/BND) show that mean western juniper cover increased $\sim 5 \%$ between the 1960 s and 1994 (Soulé et al. 2003). While increasing cover of western juniper can be a function of "the ongoing effects of canopy and stem development" (Soulé and Knapp 2000:32) the increases in establishment we find are concurrent with increasing cover, which supports the finding that rapid expansion is occurring and is not just part of a normal pattern of natality and mortality for this species.

One of the most consistent explanations proffered for the initial pulse of establishment that began on most sites in the late 1800 s to early 1900s (favorable climate combined with domestic livestock grazing) is modestly supported by our findings. Across all sites, mean growth generally remains above average $(\geq 1.0)$ from the decades of the late 1800s through the early 1900 s (Figs. 2-6). Thus, this time period can be characterized as a period when climatic conditions were favorable for growth of western juniper. Few other proxy measures of climate exist for the interior PNW, but these results also suggest that the latter half of the 19th century was climatically amenable for western juniper. For example, annual corrected stream flow data for The Dalles, Oregon $\left(45^{\circ} \mathrm{N}, 121^{\circ} \mathrm{W}\right)$, exceed the long-term mean value for $87 \%$ of the years during the first $30 \mathrm{yr}$ of available data (1879-1908; available online). ${ }^{5}$ Similarly, tree-ring studies suggest that the late 1800 s were remarkable either for above-normal precipitation (Keen 1937) or lack of severe droughts (Knapp et al. 2002).

Our observation that juveniles were found more frequently under shrubs on the disturbed sites (Table 3, with the exception of GMD/GMU) supports the theory that grazing should enhance establishment of western juniper through a combination of reduced grass cover (less competition for water and nutrients and reduced fire frequency), increased shrub cover (more nurse plants for juvenile western juniper), and enhanced seed dispersal (Burkhardt and Tisdale 1976, Bedell et al. 1993, Miller and Rose 1995). In addition, the density

${ }^{5}$ URL: 〈ftp://ftp.atmos.washington.edu/mantua/pnw_impacts/ thedalles.nat.1878_1994〉 


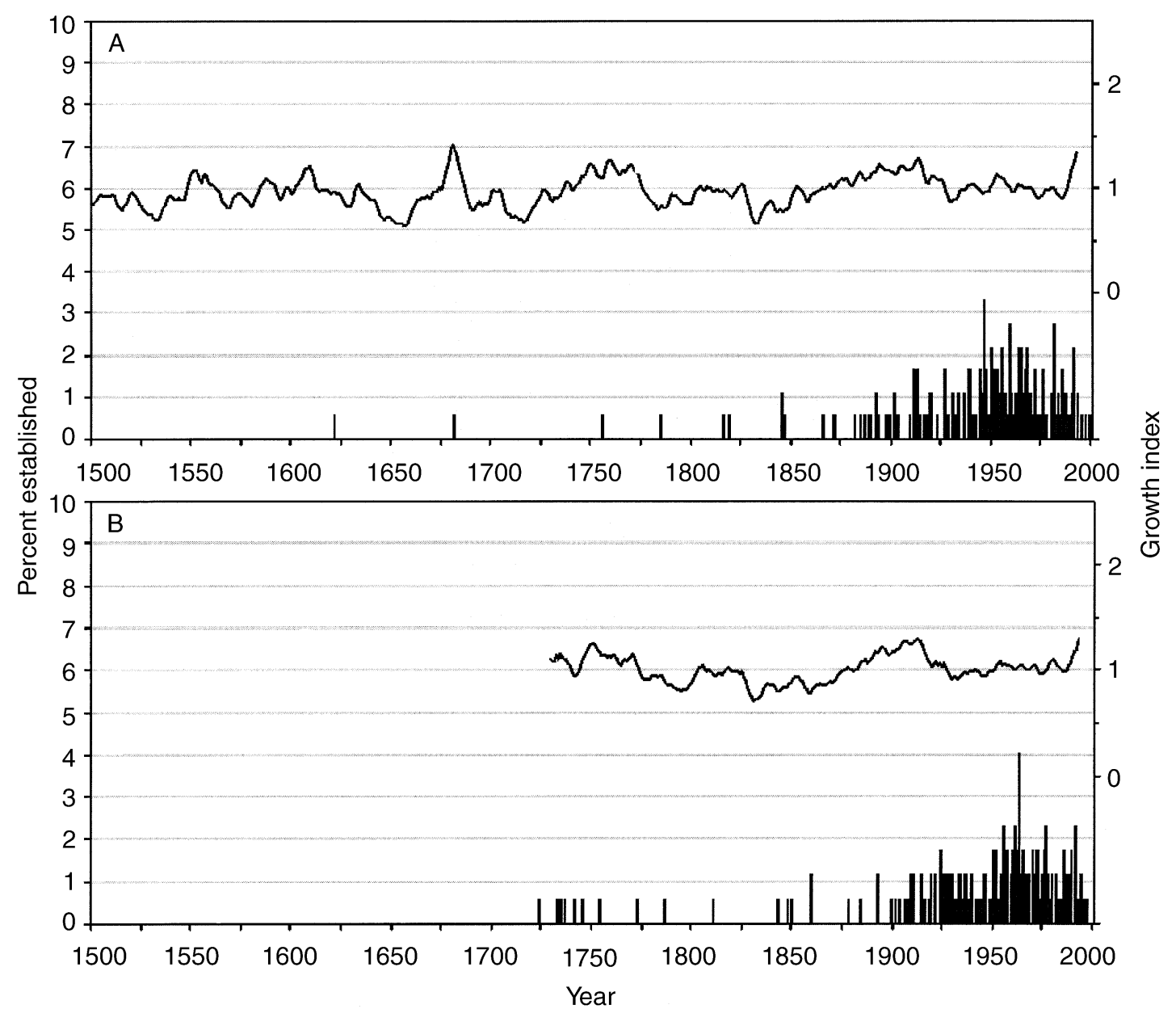

FIG. 3. Percentage of western juniper established per year (vertical bars), and 11-yr running mean of radial growth (solid line) for (A) GMU and (B) GMD.

of trees is substantially greater on the disturbed locations (Table 3), and the majority of trees have established more recently, all lines of evidence that suggest disturbance may be enhancing processes of establishment.

The potential agents of change for establishment common to all sites are fire exclusion, macroscale climatic conditions, biological inertia, and atmospheric carbon dioxide enrichment. From fire records, we know that only $\mathrm{HBD}$ has experienced any significant fire since the late 1960s (Table 1). Our site reconnaissance revealed that major fires have not likely burned any of our sites in the last century (e.g., we found only isolated burned trunks, suggesting that lightning-initiated fires have not carried, and sampling of dead but standing juniper reveals they decompose very slowly in this semiarid environment). The increasing rates of establishment support this observation because fire is typically lethal for juvenile western juniper (Burkhardt and Tisdale 1976). A long-term absence of high-severity fires should result in an increasing rate of establishment, at least until a site becomes an established wood- land, because of biological inertia (i.e., an increasing seed rain through time). The apparent lack of highseverity fires at all sites in the last century could possibly be linked to domestic livestock grazing because grazing reduces the fine fuel load needed to carry and sustain major fires, and "fire spread is more likely to be extensive [in western juniper ecosystems] if grasses rather than shrubs are the dominant fuel" (Agee 1993: 376). In addition, fire suppression efforts of the 20th century almost certainly have increased the fire return interval at individual locations (e.g., Burkhardt and Tisdale 1976, Miller and Rose 1999) and at the regional scale, thus impacting all sites. With no fire-induced mortality, all of the study sites should have experienced an increasing seed rain through time, a process especially important on the downslope, disturbed sites (HBD, PBD, STD). In characterizing the impacts of fire in western juniper communities, Agee (1993:384) states: "there are clearly areas in which fire effects were always minimal; that is why the old-growth juniper communities exist." Further, "some areas show no evidence that a herbaceous component sufficient to 


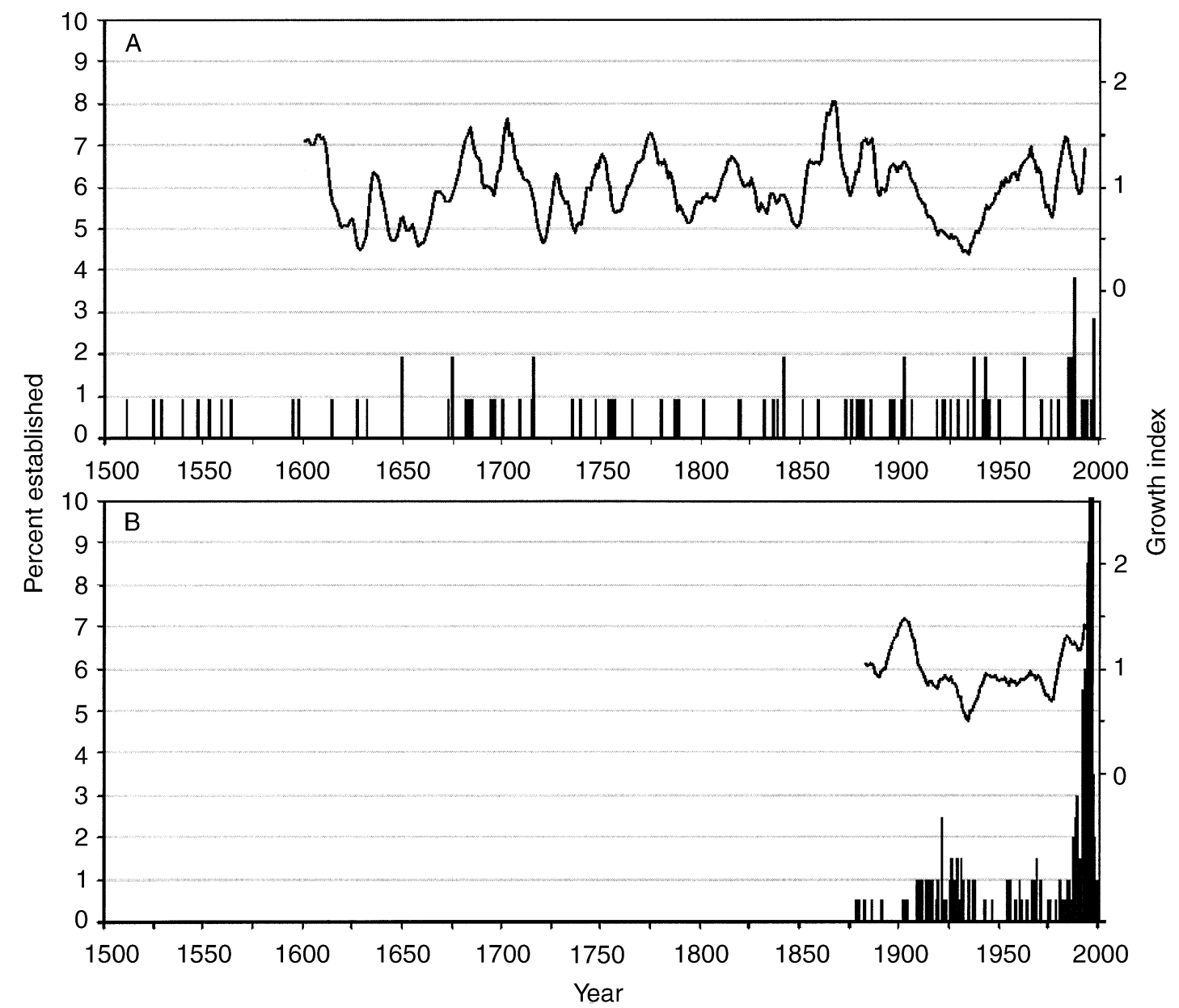

FIG. 4. Percentage of western juniper established per year (vertical bars), and 11-yr running mean of radial growth (solid line) for (A) HBU and (B) HBD.

allow fire spread ever existed." (Agee 1993:384). These descriptions apply to our three upslope, lessdisturbed sites (HBU, PBU, STU). Thus, while we recognize that fire is often a landscape-scale process and that fire return intervals within western juniper ecosystems likely increased dramatically since the late 1800s (e.g., Burkhardt and Tisdale 1976, Miller and Rose 1999) due to combined effects of domestic livestock grazing and fire suppression, its importance on at least three sites (HBU, PBU, STU) has likely always been minor and restricted to individual trees that would be struck by lightning.

The specific physiologic linkages between climate, establishment and the survival of western juniper seedlings are not well understood. For example, Burkhardt and Tisdale (1976:482) compared seedling survival with a suite of climatic variables and found "little relationship." Evans (1988:12) notes: "seed germination in juniper is not a straightforward process, but one that requires a specific sequence of environmental conditions for successful natural germination and seedling establishment." Seed production in western juniper oc- curs most years (Sowder and Mowat 1965), with more copious production occurring less frequently (Evans 1988). Bedell et al. (1993:5) state: "juniper under stress usually produces either no cones or male cones. Trees under non-stressful conditions. . . produce a high percentage of female cones." The low-stress conditions that are conducive to radial growth should also result in a healthy seed crop, thus a higher probability of plentiful seed dispersal and potential germination. Gravitational seed dispersal is common (Burkhardt and Tisdale 1976, Bedell et al. 1993), as is dispersal from birds (Evans 1988, Bedell et al. 1993) and mammals (Schupp et al. 1997). Germination is most common in April to May (Sowder and Mowat 1965, Johnsen and Alexander 1974), but may not occur until after an extended period of dormancy (one or more years) (Sowder and Mowat 1965). While specific information on rates of mortality for western juniper seedlings and juveniles is limited, Burkhardt and Tisdale (1976:482) reported a $71 \%$ survival rate of seedlings at one location in southern Idaho after a year (1967) that they characterized as "extraordinarily dry," and a $60 \%$ sur- 


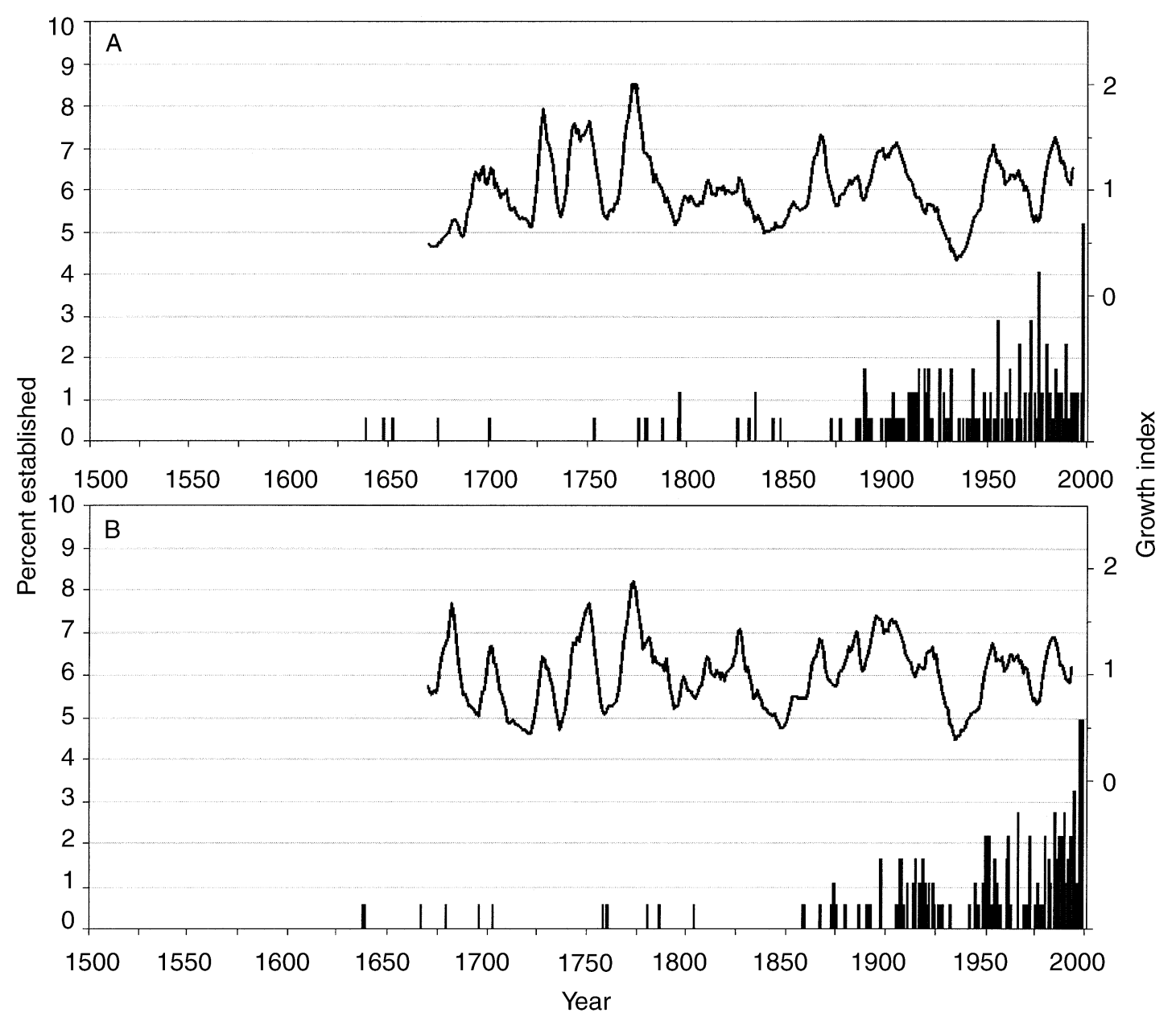

FIG. 5. Percentage of western juniper established per year (vertical bars), and 11-yr running mean of radial growth (solid line) for (A) PBU and (B) PBD.

vival rate after two years. Thus, in the absence of fire, survival rates are high, and this corresponds to observations we made at each study site in that we encountered very few dead juveniles. At the microscale, the common theory is that protection from evaporational stress provided by a host shrub is conducive to germination and subsequent survival of seedlings (Eddleman 1987, Evans 1988, Bedell et al. 1993). However, to the best of our knowledge, ours is the first study to attempt to understand potential linkages between regional-scale climatic conditions and changes as they relate to establishment of western juniper.

Our analyses suggest that two aspects of climate and climate change impact establishment. The positive and significant (at the less-disturbed sites) relationships between summer precipitation and establishment, combined with the significant positive trend of summer precipitation, leads us to deduce that juvenile western juniper and seedlings may have a lower mortality rate during a wet summer compared to a dry summer. A significant negative relationship exists between summer precipitation and summer temperature $(r=$
$-0.353, P<0.01)$. Thus, wet summers may also have a tendency to be cooler, which further reduces evaporational stress. However, we must temper these findings by noting that total June, July, and August precipitation in Oregon Climatic Division 7 (Fig. 1) averages only $4.2 \mathrm{~cm} / \mathrm{yr}(5.5 \mathrm{~cm} / \mathrm{yr}$ in Division 5), and this precipitation is often convectional in nature, spatially irregular, and subject to rapid evaporation.

One interpretation of the positive relationships between establishment and spring, summer, and annual temperatures (Table 5) is that an extended growing season enhances seed maturation and seedling viability. Upward trends in annual temperature have been shown to increase growing season length (e.g., White et al. 1999). Though not significantly related to establishment (Table 5), warmer temperatures during the spring months may enhance establishment because juvenile western juniper are cold intolerant to a hard spring freeze (Bedell et al. 1993), and warm and wet conditions in the microenvironment of the duff layer found underneath a nurse plant are theorized to be beneficial to western juniper seedlings (Eddleman 1987, Evans 


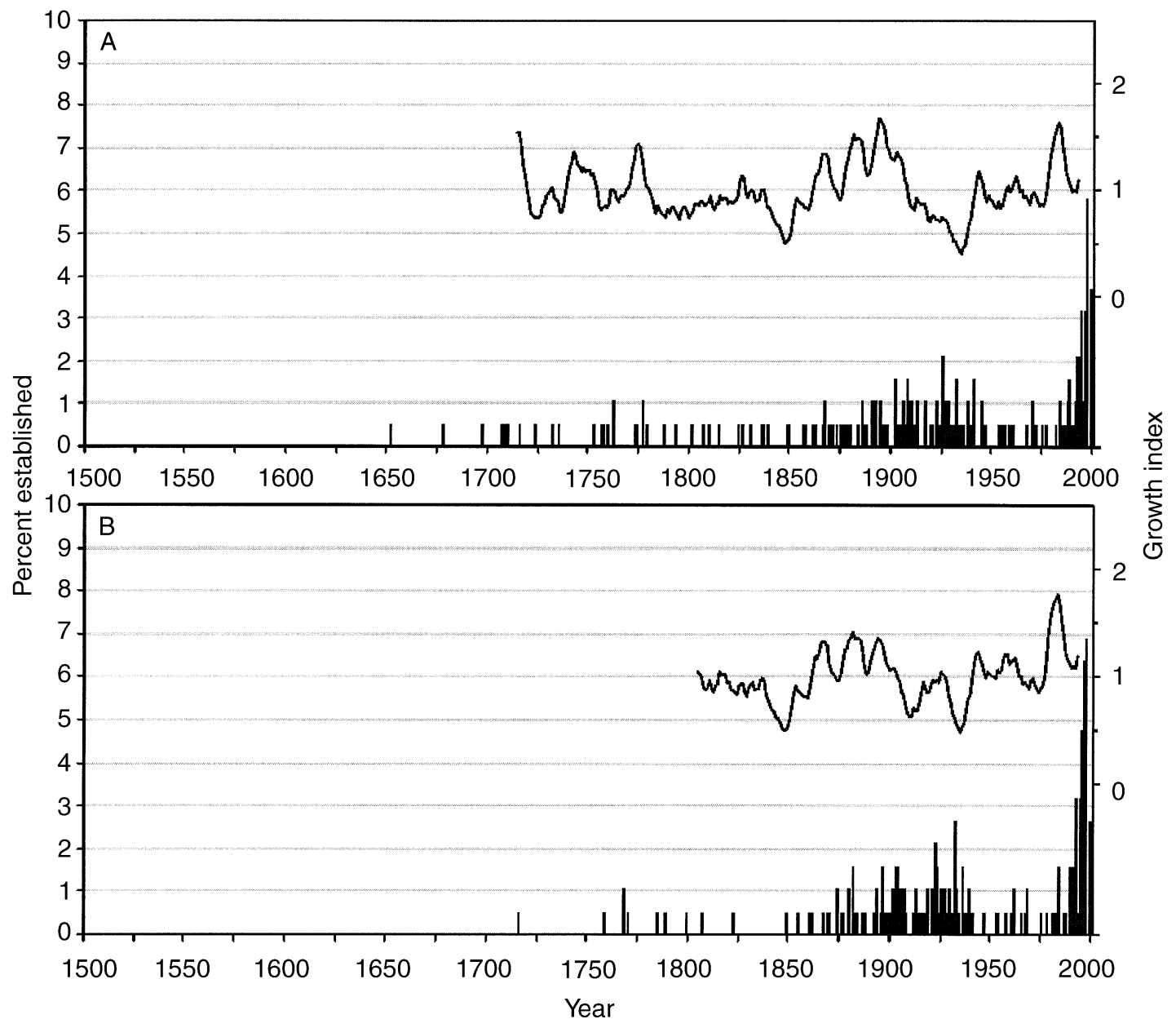

FIG. 6. Percentage of western juniper established per year (vertical bars), and 11-yr running mean of radial growth (solid line) for (A) STU and (B) STD.

1988, Bedell et al. 1993). The significant $(P<0.05$ at the combined disturbed sites), positive relationship between establishment and summer temperature is intriguing. Because temperatures can fall below freezing even during the summer months in western juniper woodlands, the same argument made for warm spring temperatures reducing freeze events could be made. In addition, the growing season would be longer in warmer summers, but no trends exist. Conversely, above normal summer temperatures should impart additional evaporative stress, which would be especially detrimental to seedlings and juveniles.

Although radial growth of western juniper responds to different climatic stimuli (Knapp et al. 2001a) than establishment, a positive relationship between radial growth of trees and establishment would be logical from the standpoint of environmental stress. The lowstress conditions that are conducive to radial growth should also result in a healthy seed crop, thus a higher probability of plentiful seed dispersal and potential germination. While there are sequences within the record where establishment and radial growth do appear to covary (Figs. 2-6), these relationships are not sustained. Lagged relationships may exist between growth and establishment. For example, the peak of the initial pulse of sustained establishment occurred in the 1920s at both less-disturbed and disturbed sites (Fig. 7), while growth was generally below average (except at GMU) in both the 1910s and 1920s (Figs. 2-6). Further, the sharp drop in establishment at the disturbed sites in the 1940s (Fig. 7) occurred a decade after the low growth values of the 1930s. However, one-decade-lagged rank correlations between growth and establishment (e.g., growth of 1920 correlated to establishment at 1930) produced no significant relationships. While soils were closely matched at each of our paired study sites, Burkhardt and Tisdale (1976:481) note that topographic position and related soil depth may factor into the paradoxical relationships between establishment and growth, as "the generally deeper and less well-drained soils of valley bottoms favored seedling establishment, whereas the shallower but well-drained soils of the upper slopes favored growth after establishment." 


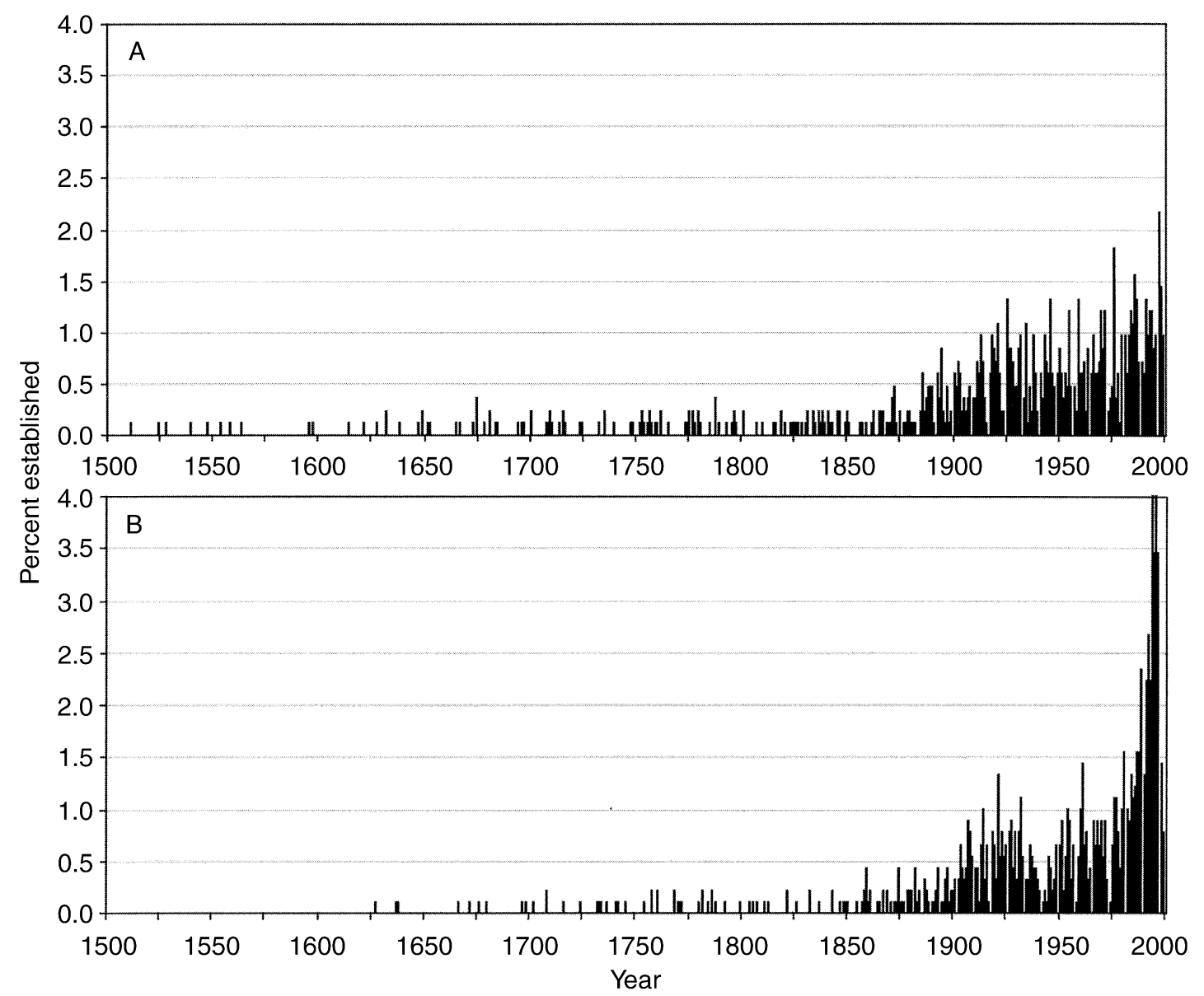

FIG. 7. Percentage of western juniper established per year for (A) all less-disturbed sites and (B) all disturbed sites.

Increasing levels of atmospheric carbon dioxide have been implicated as the primary cause of anomalous radial growth (given climate) during the latter half of the 20th century because of the ameliorative effects of increased water-use efficiency (Knapp et al. 2001a,b). With more atmospheric $\mathrm{CO}_{2}$ available, radial growth of adult juniper may occur longer into the growing

TABLE 5. Spearman rank correlations between decadal means (1890s to 1990s) of combined (all disturbed sites, all less-disturbed sites) percentage of trees established and various climatic variables derived from monthly data for Oregon Climatic Division 7.

\begin{tabular}{lll}
\hline \hline & \multicolumn{2}{c}{ Spearman correlation $(P)$} \\
\cline { 2 - 3 } Climate variable & Less disturbed & Disturbed \\
\hline Precipitation & & \\
June-August & $0.681(0.021)$ & $0.479(0.136)$ \\
$\quad$ October-June & $0.083(0.808)$ & $0.026(0.939)$ \\
Temperature & & \\
$\quad$ Annual & $0.571(0.066)$ & $0.636(0.035)$ \\
Spring & $0.458(0.156)$ & $0.308(0.357)$ \\
Summer & $0.587(0.058)$ & $0.619(0.042)$ \\
\hline
\end{tabular}

Note: 1890s include 1896-1899; 1990s include 1990-1998. season and be less impacted during drought conditions. Accordingly, western juniper growth post-1950 increased significantly (mean increase of $23 \%$ ) compared to the pre-1950 period, and the relative growth increases were especially pronounced during drought years (63\% increases) (Knapp et al. 2001a). Similarly, we posit that carbon dioxide enrichment stimulates western juniper establishment in two ways. First, drought stress affecting perennial species is reduced because of the potential ameliorating effects of plant/water relations (i.e., water-use efficiency, stomatal conductance/ leaf water potential, seedling survivorship) (Arp et al. 1998, Tognetti et al. 1998, 2000a, $b$, Centritto et al. 1999, Feng 1999, Polley et al. 1999, Wullschleger et al. 2002). Second, with improved water relations, western juniper establishment downslope (e.g., HBD, PBD, STD) into areas that had previously been too water limiting to support more than a widely dispersed pattern of juniper is possible. Downslope expansion clearly appears to be occurring at HBD, PBD, and STD, as the combined ratio of percent juvenile to percent adult across these three sites is $53.3 \%$ to $46.7 \%$, whereas only $37.7 \%$ of trees are juvenile $(62.3 \%$ adult $)$ across their three matched sites (HBU, PBU, STU) (Table 3). 


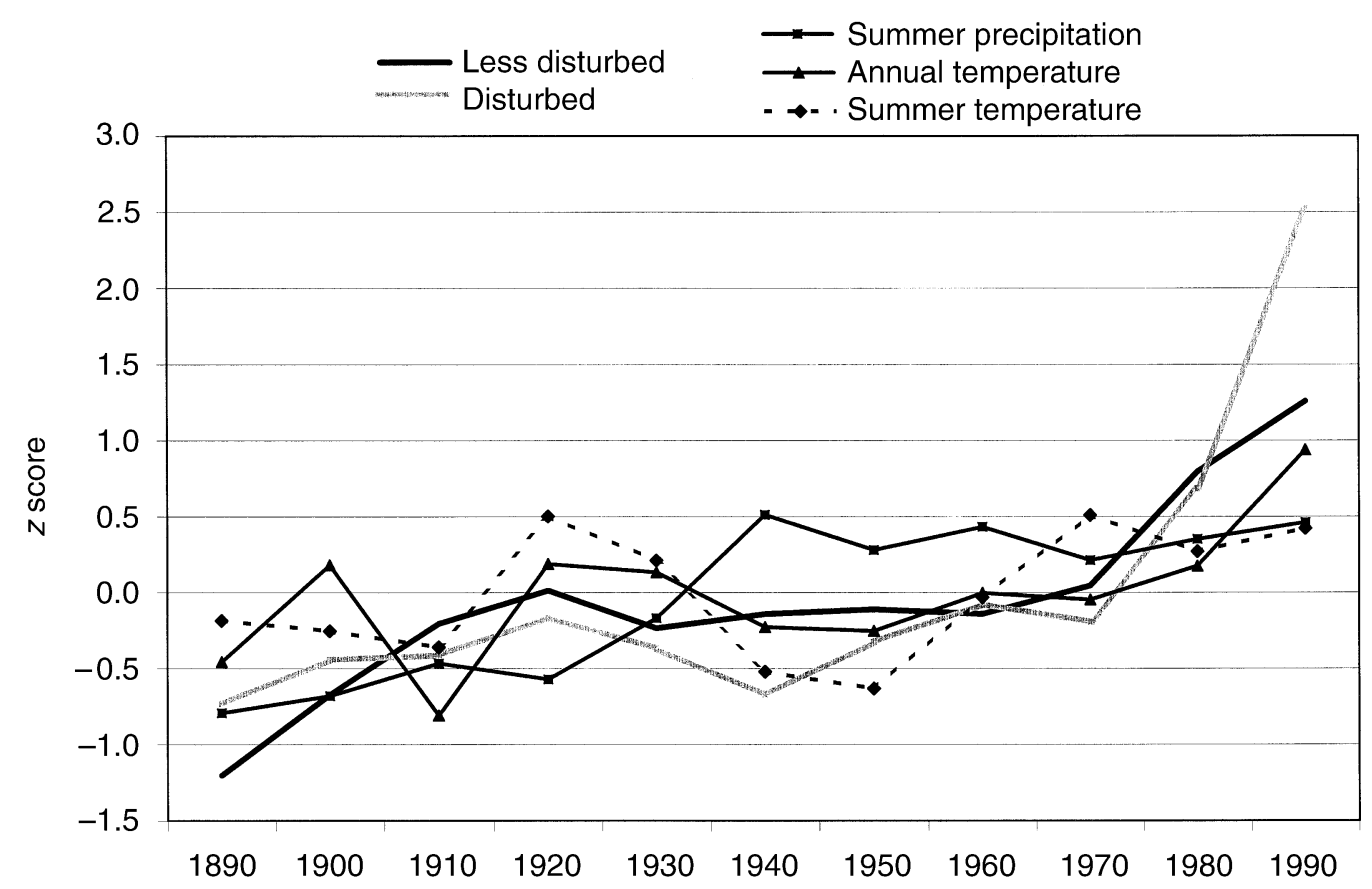

FIG. 8. Mean standardized scores per decade for the combined disturbed study sites, combined less-disturbed study sites, summer (June-August) precipitation, annual temperature, and summer temperature. Climatic data from Oregon Climatic Division 7.

Further, the mean percentage of trees establishing after 1960 at HBD, PBD, and STD is $50.5 \%$, while it is only $31.3 \%$ at $\mathrm{HBU}, \mathrm{PBU}$, and STU. In addition, $\mathrm{CO}_{2}$ enrichment has been shown to have "strong [positive] impacts on physiological performance" (Hamerlynck et al. 2000:183) on woody species seedlings during periods of drought and/or extreme high temperatures, a response that has been exhibited in both arid (Hamerlynck et al. 2000) and semiarid environments (Polley et al. 1999, Maherali and DeLucia 2000, Polle et al. 2001).

Young and Evans (1981) and Soulé and Knapp (2000:31) have noted that a "cover/density threshold" may exist for western juniper. Less disturbed upslope sites (such as HBU) are established woodlands that can have a relatively steady-state establishment history in part because they lack suitable establishment locations and have excessive resource demands from existing trees. Because there are substantially more trees on the disturbed sites, and these trees have generally established more recently, we find that disturbance (primarily domestic livestock grazing) does impact the establishment history of western juniper. However, even in the absence of domestic livestock grazing, establishment rates are generally trending upward, a result that leads us to conclude that active domestic livestock grazing is not required for enhancement of establishment. Therefore, multiple driving forces are controlling establishment patterns of western juniper in Oregon.

The second pulse of establishment occurred on both disturbed and less-disturbed sites indicating that a dif- ferent set of mechanisms was largely responsible. The post-1940s pulse occurred during a period with increasing rates of radial growth (Knapp et al. 2001a), increasing atmospheric $\mathrm{CO}_{2}$, increasing summer precipitation, and increasing annual temperature. In addition, this pulse is related to the effects of biological inertia as the trees that established in the first pulse (late 1800 s to early 1900 s) became fully reproductive. Our conclusions are consistent with several recent studies on woodland species in the southwestern United States, which reported that (1) "woody plant encroachment into grasslands can be high, regardless of grazing pressure. . " (Brown and Archer 1999:2393), (2) "increases in summer precipitation increased seedling emergence and recruitment rates as much as threefold", (Weltzin and McPherson 2000:1902), (3) seedling survivorship significantly increased under elevated atmospheric $\mathrm{CO}_{2}$ (Polley et al. 1999), and (4) juniper woodlands have expanded since the late 1800s, and that semiarid tree species are no longer confined to rocky outcrops (Ueckert et al. 2001).

In summary, we emphasize that the relative contributions of agents of change can exhibit significant temporal variability, and that new agents may emerge. In this study, we found that the traditionally cited disturbance mechanisms can accelerate establishment rates of western juniper, especially with domestic livestock grazing on sites that are downslope from established woodlands. However, we also found that establishment rates are generally accelerated regardless of the active disturbance regime, suggesting some other driving 
mechanism has either appeared, or become more dominant. In the absence of significant climatic changes or other major changes in the disturbance regime (e.g., an increasing frequency of major fires), establishment rates will continue to increase during the 21 st century as the large group of trees establishing in the post1940 s period become fully reproductive. Thus, the current scientific and land management concerns associated with western juniper expansion will become more acute in upcoming decades.

\section{ACKNOWLEDGMENTS}

This study was funded by the National Science Foundation grant \#SBR-9809245, and by an Appalachian State University Research Council Grant. We thank Harry Blount, Stacy Carnine, Joel Davis, Betsy Herrmann, Kimberly Eldridge, Allison Miller, Paul Mitchell, Andrew Paul, and Mark Pelfrey for field and/or lab assistance. We also thank Will Fontanez of The University of Tennessee Cartographic Services Laboratory for production of Fig. 1, and Dr. Glen M. MacDonald and two anonymous reviewers for their constructive comments.

\section{Literature Cited}

Agee, J. K. 1993. Fire ecology of Pacific Northwest forests. Island Press, Washington, D.C., USA.

Applequist, M. B. 1958. A simple pith locator for use with off-center increment cores. Journal of Forestry 56:141.

Archer, S. 1994. Woody plant encroachment into southwestern grasslands and savanna: rates, patterns and proximate causes. Pages 13-68 in M. Vavra, W. A. Laycock, and R. D. Pieper, editors. Ecological implications of livestock herbivory in the West. Society of Range Management, Denver, Colorado, USA.

Archer, S., D. S. Schimel, and E. A. Holland. 1995. Mechanisms of shrubland expansion: land use, climate or $\mathrm{CO}_{2}$ ? Climatic Change 29:91-99.

Arp, W. J., J. E. M. Van Mierlo, F. Berendse, and W. Snijders. 1998. Interactions between elevated $\mathrm{CO}_{2}$ concentration, nitrogen and water: effects on growth and water use of six perennial plant species. Plant, Cell and Environment 21: $1-11$.

Bedell, T. E., L. E. Eddleman, T. Deboodt, and C. C. Jacks. 1993. Western juniper: its impact and management on Oregon rangelands. Oregon State University Extension Service EC 1417, Corvallis, Oregon, USA.

Bond, W. J., and G. F. Midgley. 2000. A proposed $\mathrm{CO}_{2-}$ controlled mechanism of woody plant invasion in grasslands and savanna. Global Change Biology 6:865-869.

Briffa, K. R., P. D. Jones, F. H. Schweingruber, W. Karlen, and S. G. Shiyatov. 1996. Tree-ring variables as proxyindicators: problems with low-frequency signals. Pages 941 in P. D. Jones, R. S. Bradley, and J. Jouzel, editors. Climatic variations and forcing mechanisms of the last 2000 years. NATO ASI Series I41. Springer-Verlag, Berlin, Germany.

Brown, J. R., and S. Archer. 1999. Shrub invasion of grassland: recruitment is continuous and not regulated by herbaceous biomass or density. Ecology 80:2385-2396.

Burkhardt, J. W., and E. W. Tisdale. 1976. The causes of juniper invasion in southwestern Idaho. Ecology 57:472484.

Burt, J. E., and G. M. Barber. 1996. Elementary statistics for geographers. Guilford Press, New York, New York, USA.

Centritto, M., H. S. J. Lee, and P. G. Jarvis. 1999. Interactive effects of elevated $\mathrm{CO}_{2}$ and drought on cherry (Prunus avium) seedlings. I. Growth, whole-plant water use efficiency and water loss. New Phytologist 141:129-140.
Cook, E. R. 1985. A time series analysis approach to tree ring standardization. Dissertation. University of Arizona, Tucson, Arizona, USA.

Eddleman, L. E. 1987. Establishment and stand development of western juniper in central Oregon. Pages 255-259 in R. V. Everett, editor. Proceedings-pinyon-juniper conference. USDA Forest Service General Technical Report GTR-INT-215.

Evans, R. A. 1988. Management of pinyon-juniper woodland. USDA Forest Service General Technical Report GTR-INT-249.

Feng, X. 1999. Trends in intrinsic water-use efficiency of natural trees for the past 100-200 years: a response to atmospheric $\mathrm{CO}_{2}$ concentration. Geochimica et Cosmochimica Acta 63:1891-1903.

Fritts, H. C. 2001. Tree rings and climate. Blackburn Press, Caldwell, New Jersey, USA.

Gedney, D. R., D. L. Azuma, C. L. Bolsinger, and N. McKay. 1999. Western juniper in eastern Oregon. USDA Forest Service General Technical Report PNW-GTR-464.

Grissino-Mayer, H. D. 1996. A 2129-year reconstruction of precipitation for northwestern New Mexico, USA. Pages 191-204 in J. S. Dean, D. M. Meko, and T. W. Swetnam, editors. Tree rings, environment, and humanity. University of Arizona, Tucson, Arizona, USA.

Grissino-Mayer, H. D. 2001. Assessing crossdating accuracy: a manual and tutorial for the computer program COFECHA. Tree-Ring Research 57:205-221.

Hamerlynck, E. P., T. E. Huxman, M. E. Loik, and S. D. Smith. 2000. Effects of extreme high temperature, drought and elevated $\mathrm{CO}_{2}$ on photosynthesis of the Mojave Desert evergreen shrub, Larrea tridentata. Plant Ecology 148:183193.

Holmes, R. L. 1983. Computer-assisted quality control in tree-ring dating and measurement. Tree-Ring Bulletin 43: 69-78.

Johnsen, T. N., Jr., and R. A. Alexander. 1974. Juniperus L. Juniper. Pages 460-469 in C. S. Schopmeyer, technical coordinator. Seeds of woody plants in the United States. USDA Agriculture Handbook 450. U.S. Government Printing Office, Washington, D.C., USA.

Keen, F. P. 1937. Climatic cycles in eastern Oregon as indicated by tree rings. Monthly Weather Review 65:175188.

Knapp, P. A., and P. T. Soulé. 1998. Recent expansion of western juniper on a near-relict site in central Oregon. Global Change Biology 4:347-357.

Knapp, P. A., and P. T. Soulé. 1999. Geographical distribution of an 18th century heart rot outbreak in western juniper (Juniperus occidentalis ssp. occidentalis Hook). Journal of Arid Environments 41:247-256.

Knapp, P. A., P. T. Soulé, and H. D. Grissino-Mayer. $2001 a$. Detecting potential regional effects of increased atmospheric $\mathrm{CO}_{2}$ on growth rates of western juniper. Global Change Biology 7:1-15.

Knapp, P. A., P. T. Soulé, and H. D. Grissino-Mayer. $2001 b$. Post-drought growth responses of western juniper (Juniperus occidentalis var. occidentalis) in central Oregon. Geophysical Research Letters 28:2657-2660.

Knapp, P. A., P. T. Soulé, and H. D. Grissino-Mayer. 2002. Climatic regionalization and the spatio-temporal occurrence of extreme single-year drought events (1500-1998) in the interior Pacific Northwest, USA. Quaternary Research 58:226-233.

Maherali, H., and E. H. DeLucia. 2000. Interactive effects of elevated $\mathrm{CO}_{2}$ and temperature on water transport in ponderosa pine. American Journal of Botany 87:243-249.

McPherson, G. R., H. A. Wright, and D. B. Webster. 1988. Patterns of shrub invasion in semiarid Texas grasslands. American Midland Naturalist 120:391-397. 
Miller, R. F., and J. A. Rose. 1995. Historic expansion of Juniperus occidentalis (western juniper) in southeastern Oregon. Great Basin Naturalist 55:37-45.

Miller, R. F., and J. A. Rose. 1999. Fire history and western juniper encroachment in sagebrush steppe. Journal of Range Management 52:550-559.

Miller, R. F., and P. E. Wigand. 1994. Holocene changes in semiarid pinyon-juniper woodlands. BioScience 44:465474.

Natural Heritage Advisory Council to the State Land Board. 1998. Oregon natural heritage plan. State of Oregon, Salem, Oregon, USA.

Palmer, W. 1965. Meteorological drought. U.S. Government Printing Office, Washington, D.C., USA.

Polle, A., I. McKee, and L. Blaschke. 2001. Altered physiological and growth responses to elevated $\left[\mathrm{CO}_{2}\right]$ in offspring from holm oak (Quercus ilex L.) mother trees with lifetime exposures to naturally elevated $\left[\mathrm{CO}_{2}\right]$. Plant, Cell and Environment 24:1075-1083.

Polley, H. W., C. R. Tischler, H. B. Johnson, and R. E. Pennington. 1999. Growth, water relations, and survival of drought-exposed seedlings from six maternal families of honey mesquite (Prosopis glandulosa): responses to $\mathrm{CO}_{2}$ enrichment. Tree Physiology 19:359-366.

Schlotzhauer, S. D., and R. C. Littell. 1986. SAS system for elementary statistical analysis. SAS Institute, Cary, North Carolina, USA.

Schupp, E. W., J. M. Gómez, J. E. Jiménez, and M. Fuentes. 1997. Dispersal of Juniperus occidentalis (western juniper) seeds by frugivorous mammals on Juniper Mountain, southeastern Oregon. Great Basin Naturalist 57:74-78.

Sims Waichler, W., R. F. Miller, and P. S. Doescher. 2001. Community characteristics of old-growth western juniper woodlands. Journal of Range Management 54:518-527.

Soulé, P. T., and P. A. Knapp. 2000. Juniperus occidentalis (western juniper) establishment history on two minimally disturbed research natural areas in central Oregon. Western North American Naturalist 60:26-33.

Soulé, P. T., P. A. Knapp, and H. D. Grissino-Mayer. 2003. Comparative rates of western juniper afforestation in southcentral Oregon and the role of anthropogenic disturbance. Professional Geographer 55:43-56.

Sowder, J. E., and E. L. Mowat. 1965. Western juniper (Juniperus occidentalis Hook.). Pages 2223-2225 in H. A. Fowells, compiler. Silvics of forest trees of the United States. USDA Agriculture Handbook 271. USDA Forest Service, Washington, D.C., USA.

Stokes, M. A., and T. L. Smiley. 1996. An introduction to tree-ring dating. University of Arizona Press, Tucson, Arizona, USA.
Tausch, R. J., and R. S. Nowak. 1999. Fifty years of ecotone change between shrub and tree dominance in the Jack Springs Research Natural Area. Pages 71-77 in E. D. McArthur, W. K. Ostler, and C. L. Wambolt, compilers. Proceedings, shrubland ecotones. USDA Forest Service Proceedings RMRS-P-11.

Telewski, F. W. 1993. Determining the germination date of woody plants: a proposed method for locating the root/ shoot interface. Tree-Ring Bulletin 53:13-16.

Tognetti, R., J. D. Johnson, M. Michelozzi, and A. Raschi. 1998. Response of foliar metabolism in mature trees of Quercus pubescens and Quercus ilex to long-term elevated $\mathrm{CO}_{2}$. Environmental and Experimental Botany 39:233-245.

Tognetti, R., A. Minnocci, J. Penuelas, A. Raschi, and M. B. Jones. 2000a. Comparative field water relations of three Mediterranean shrub species co-occurring at a natural $\mathrm{CO}_{2}$ vent. Journal of Experimental Botany 51:1135-1146.

Tognetti, R., A. Raschi, and M. B. Jones. 2000b. Seasonal patterns of tissue water relations in three Mediterranean shrubs co-occurring at a natural $\mathrm{CO}_{2}$ spring. Plant, Cell and Environment 23:1341-1351.

Ueckert, D. N., R. N. Phillips, J. L. Petersen, X. Ben Wu, and D. F. Waldron. 2001. Redberry juniper canopy cover dynamics on western Texas rangelands. Journal of Range Management 54:603-610.

Wall, T. B., R. F. Miller, and T. J. Svejcar. 2001. Juniper encroachment into aspen in the Northwest Great Basin. Journal of Range Management 54:691-698.

Weltzin, J. F., and G. R. McPherson. 2000. Implications of precipitation redistribution. Ecology 81:1902-1913.

West, N. E. 1983. Western intermountain sagebrush steppe. Pages 375-397 in N. E. West, editor. Temperate deserts and semideserts. Elsevier Press, Amsterdam, The Netherlands.

West, N. E. 1999. Juniper pinyon savannas and woodlands of western North America. Pages 288-308 in R. C. Anderson, J. S. Fralish, and J. M. Baskin, editors. Savannas, barrens and rock outcrop plant communities of North America. Cambridge University Press, New York, New York, USA.

White, M. A., S. W. Running, and P. E. Thornton. 1999. The impact of growing-season length variability on carbon assimilation and evapotranspiration over 88 years in the eastern US deciduous forest. International Journal of Biometeorology 42:139-145.

Wullschleger, S. D., T. J. Tschaplinski, and R. J. Norby. 2002. Plant water relations at elevated $\mathrm{CO}_{2}$-implications for the future. Plant, Cell and Environment 25:319-331.

Yamaguchi, D. K. 1991. A simple method for cross-dating increment cores from living trees. Canadian Journal of Forest Research 21:414-416.

Young, J. A., and R. A. Evans. 1981. Demography and fire history of a western juniper stand. Journal of Range Management 34:501-506. 